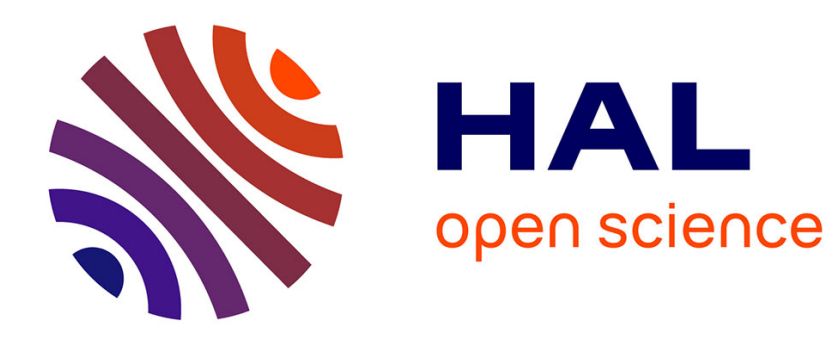

\title{
Caribbean, South and Central America
}

Bettina M Migge

\section{To cite this version:}

Bettina M Migge. Caribbean, South and Central America. The Routledge Handbook of Pidgin and Creole Language, Miriam Meyerhoff \& Umberto Ansaldo (eds.), 150-178. Malden, MA: Routledge., 2020. hal-03085559

\section{HAL Id: hal-03085559 https://hal.science/hal-03085559}

Submitted on 21 Dec 2020

HAL is a multi-disciplinary open access archive for the deposit and dissemination of scientific research documents, whether they are published or not. The documents may come from teaching and research institutions in France or abroad, or from public or private research centers.
L'archive ouverte pluridisciplinaire HAL, est destinée au dépôt et à la diffusion de documents scientifiques de niveau recherche, publiés ou non, émanant des établissements d'enseignement et de recherche français ou étrangers, des laboratoires publics ou privés. 


\section{Caribbean, South and Central America}

Bettina Migge

\section{INTRODUCTION}

The Caribbean, South and Central America are a vast region that has been significantly affected by European colonial expansion. The experience was by no means homogeneous across the region. While the latter two regions were mainly dominated and influenced by Spain and to a lesser extent Portugal (South America), the Caribbean and the Guiana region of South America were subject to expansionist activities from a number of European nations (Denmark, England, France, Netherlands, Spain). Official political dependency on Europe also lasted much longer and still continues in some cases in the Caribbean and the Guiana region while it ended for the most part in the early $19^{\text {th }}$ century in the other two regions. In all three regions, European expansionist activities focused on exploitation of the region's natural resources and led to a significant reconfiguration of the population. Native American peoples from the pre-Columbian period were decimated in all of them and were replaced by people from outside of the region (enslaved Africans, indentured Asians and Europeans and Europedescent populations). Contact between these population groups gave rise to new ones, including new cultural and linguistic patterns. The latter are the subject of this chapter. On the one hand, it will sketch the types of contact patterns, the circumstances that brought them about and their outcomes and, on the other hand, it will present the field investigating them, outlining the issues, approaches, controversies and main findings.

The English-official Caribbean (that is, the parts of the Caribbean where English has official status) has taken a lead role in pursuing research on Pidgin and Creoles languages (P/Cs) over the past few centuries. According Holm (1988: 17-18), Moravian missionaries began describing creoles in the 1730s for the purpose of religious conversion, beginning in 
Suriname and the island of St Thomas. By 1770 they published the first-ever grammar of a creole, namely the variety spoken in St Thomas and St Croix. Much later in the 20th century, the Caribbean was also instrumental in consolidating the field into an academic discipline as the first two major conferences on P/Cs were held in 1959 and 1968 at the Mona, Jamaica, campus of the University of the West Indies (Kouwenberg \& Singler 2008: 2-3). These two conferences (see the proceedings in Hymes 1971) were pivotal in garnering scholarly attention to P/Cs as respectable subjects of linguistic research. Many leading scholars in the field also either originated from the English-official Caribbean or undertook research there.

From 1972 onwards the Society for Caribbean Linguistics and later the Society for Pidgin and Creoles Linguistics (founded in 1989) has supported research and applied goals in effecting positive change in creole-speaking communities, particularly in the Caribbean. South and Central America, outside of Suriname and Guyana, has had lower prominence in the field. This is however slowly changing due to a greater interest in Spanish-based and minority $\mathrm{P} / \mathrm{Cs}$ which has brought additional territories, languages and contact settings into focus (e.g. Lipski 2005; Schwegler 2000; McWhorter 2000). There are also a number of French-official countries in the region. Research on French-based P/Cs has been conducted in part through the Comité International des Études Créoles founded in 1976.

The remainder of this contribution is structured as follows. Section 2 gives a very broad overview of the three regions. Section 3 first presents the types of contact settings that have existed in the region and then discusses linguistic details relating to some of the more emblematic outcomes of contact. The main lines of linguistic research and theoretical debates (creole genesis, sociolinguistics of Pidgins and Creoles (PCs) and applied linguistics issues) are discussed in sections 4-6. 


\section{A SNAPSHOT OF THE GEOGRAPHICAL AND HISTORICAL CONTEXT OF THE REGION}

The three regions do not form a natural entity due to differences in their physical makeup and their partially different historical developments. I broadly present each and then summarize some important properties. The Caribbean Sea is the seventh largest body of water in the world, located between Central and South America (primarily Venezuela) to the south, the Gulf of Mexico to the west, and the North Atlantic Ocean to the north and east. It encompasses several island chains (totaling approximately 7000 islands, islets, and cays), including the Greater Antilles to the north and the Lesser Antilles to the east.

Between 1630 and 1770 Caribbean territories underwent an intense period of colonization, with sustained conflict and rivalry between European powers, leading to frequent changes in ownership of colonies driven by the pursuit of profits in sugar agriculture and from slavery. By the end of this period all Caribbean lands had come under European control with territorial acquisition shaped by the slave trade economy (Higman 2011: 109112). Native American populations of Arawak and Carib origin were effectively replaced by African and European populations, with European languages and creoles arising from contact thenceforth dominating the region.

Even after the end of slavery, the Caribbean region continued under the yoke of European colonialism in contrast to much of Central and South America. By 1900 only Cuba, Haiti, and the Dominican Republic had achieved independence. Even today only 13 of the 24 polities of the Caribbean have fully independent representation in the United Nations (Higman 2011: 7). The others 'belong' to other nations such as the United Kingdom, France, the United States, Columbia, and Venezuela. Thus Guadeloupe and Martinique are insular regions of France, Puerto Rico is a territory of the U.S., and Monserrat Cayman Islands is a British Overseas Territory. Caribbean countries and territories also share populations and 
political memberships with Central and South American nations (including Suriname, Guyana, French Guiana, Belize, Panama, Costa Rica, and Nicaragua). Jamaicans, for example, were employed in the railroad construction project in the Limón region of Costa Rica in the late 19th century and participated in the construction of the Panama Canal in the early 20th century.

Central America currently consists of seven independent nation states and is home to no less than 45 indigenous population groups (Foster 2007: xi). It is bordered by Mexico to the north and Columbia to the south, functioning as a bridge between the two American subcontinents with the Pacific Ocean to the west and the Atlantic Ocean to the east. Five of the states of Central America, Nicaragua, Honduras, Guatemala, El Salvador, Costa Rica, share a long history because under Spanish rule they were administered as part of the Kingdom of Guatemala for several centuries.

During Spanish rule, the native Amerindian population was decimated throughout the region and except for Costa Rica, a two-tier society emerged where people of Spanish origin constituted the dominant class and everyone else, comprising Amerindians, Mestizos (people of mixed Spanish-Amerindian origin), and enslaved Africans made up the lower class (Booth \& Walker 1993: 19). After independence in 1823, these states formed a short-lived federation which fell apart around 1838. The two-tiered society endured and the economy continued to focus on production and export of agricultural products such as coffee, which concentrated power into the hands of the elite and forced Mestizo locals into work on these plantations.

The most common language in Central America is Spanish in its various forms, but there are also millions of speakers of Miskito (Misumalpan) and Mayan languages, and English-based creoles are found in Nicaragua, Costa Rica, and Panama. Unlike other Central American countries, Belize was governed as a British colony from 1840 to 1981. Linguistically it resembles Caribbean countries with English-based creoles, with the creole- 
speaking population arising as a consequence of the logwood trade (Escure 2013a). English serves as the official medium of instruction in schools and language of government, Spanish is widely spoken as a first language in Mestizo populations, and Garifuna (a mixed Arawakan-Carib language belonging to a people originally from St Vincent and Dominica with African and indigenous ancestry) has smaller speech communities in Honduras, Guatemala, and Belize. Panama differs from other Central American nations in initially joining forces with the southern Federation (Colombia, Ecuador, Peru, Bolivia and Venezuela) after independence. Panama remained linked to Colombia after the Federation's dissolution and only achieved independence from Colombia in 1903. In subsequent years many people from the Caribbean and further afield came to Panama to support the massive effort of building the Panama Canal which was officially opened in 1920. Most of its population speaks Spanish but small communities on the Caribbean coast speak both vernacular English and a creole originating with immigrant populations from Jamaica and other Caribbean islands.

South America itself spans a vast subcontinent stretching from the Panama-Columbia border to the southern tip of Chile and is surrounded by the Atlantic Ocean, the Gulf of Mexico, and Pacific Ocean. It includes twelve independent countries (the largest of which is Brazil), two British territories, and an overseas department and region of France (French Guiana). The countries colonized by Spain as well as Brazil, colonized by Portugal, are often treated as a unit under the label of Latin America as they share colonial and religious similarities (the impact of the Catholic Church) but are still socially and economically diverse.

After independence, countries in the main exploited their natural resources (mining of silver, gold) and engaged in agricultural activities (e.g. sugar plantations in the Guiana region and Brazil) to supply European and North America markets. This led to the emergence of 
plantation and mining societies and the subordination of indigenous societies, destroying their social structure and traditional livelihood. The extent of this destruction differed across this vast region, depending on the nature of exploitable resources. Indigenous rural populations, African-descent populations, and later also immigrants from Europe provided the labour for the mines and plantations, and eventually also contributed to the rapid growth of the cities. South American states were led by European-descent elites and the relative power as well as the relative proportions of indigenous, European immigrant populations and African-descent populations differed widely from country to country (Archetti et al. 1987; Bakewell 1998). The main languages spoken are varieties of Spanish and Portuguese (Brazil) and native American languages have been under threat since colonial times.

The Guiana region (French Guiana, Suriname and Guyana) differs from Latin American states in that they were colonized by France, the Netherlands and England and also stayed under colonial rule well into the latter part of the 20st century; French Guiana is still an overseas region of France. All three are ethnically diverse and in all of them indigenous American populations constitute tiny minorities of the population while African-descent populations are dominant though changes have occurred since independence with Asian immigrant populations constituting increasingly larger proportions of the society in Suriname and Guyana. All three countries are linguistically very diverse and there is migration between them in that Afro-Guyanese have migrated to Suriname and French Guiana and AfroSurinamese Maroons make up an important section of the French Guianese population (see Migge \& Léglise 2015; Price \& Price 2003). Besides European languages that serve as the main media in the official domain, creole languages play an important role in society. Asian immigrant languages and Amerindian languages are under pressure from both these languages. 
<< Map here >> [see Schneider 2011 - details sent to Miriam]

In summary then, while these regions are quite different, there are broad similarities in some respects. First, in the pre-Columbian period, indigenous populations of Native Americans inhabited most of the territories. Second, these flourishing societies came under pressure from European nations seeking wealth and larger zones of influence starting with Christopher Columbus' first expedition in 1492. Third, while 'early' colonizers, Spain and Portugal, focused their activities mainly on Central and South America, 'later' ones (Britain, France, Netherlands) concentrated on the Caribbean and the Guyana region. Fourth, colonization completely changed populations in all three regions. As indigenous populations diminished particularly in the Caribbean but also in South American plantation economies, colonizers replaced them with enslaved Africans from the Senegambia, Sierra Leone, Windward Coast, Bight of Benin and Gold Coast (Eltis 2018). African-descent populations quickly outnumbered indigenous peoples and European-descent populations in Caribbean and some South American colonies. In Central and South America Mestizo populations outnumbered indigenous American populations. Fifth, in some Caribbean and South American countries, labourers from India (Guyana, Trinidad, Tobago) or India, China and Indonesia (Suriname) replaced African-descent plantation labourers after the end of slavery, further diversifying societies. Sixth, societies were stratified on the basis of race or ethnicity and occupation, with European-descent populations constituting the local elites even after independence. Seventh, one group that emerged across the Caribbean and South America were Maroons. They were communities formed by enslaved people who ran away from plantations to escape slavery. They "dotted the fringes of plantation America from Brazil to the southwestern United States, from Peru to the American South." (Price 1996: 1). In some colonies, such as some French islands, communities were very small and did not much affect 
the colony while in others, such as Suriname, communities were large and destabilized the plantation economy. Planters and colonial administrations had to invest a lot of resources to fight them because they usually settled in inaccessible areas and were skilled in warfare. At times, colonies had to sign treaties that guaranteed Maroon communities territorial rights, freedom and the provision of economic goods (Price 1996: 3). Communities initially consisted of large proportions of men, African-born persons and skilled laborers. They remained dependent on the plantation economy for some of their goods and initially also for new members, suggesting that they were not socially isolated but that their social and language practices impacted colonial ones and vice versa. All communities are nowadays under pressure to integrate into mainstream society, but generally conceive of their communities as separate cultural entities.

The contact and mixing of populations over many generations has produced a rich tapestry language contact and given rise to new languages. This will be broadly sketched in next section.

\section{CONTACT LANGUAGES IN SOUTH AND CENTRAL AMERICA AND THE CARIBBEAN}

Bilingualism and multilingualism as well as language contact phenomena have been common in the three regions since the pre-Columbian era. A general overview of the kinds of contact settings and outcomes that existed in the three regions is presented in 3.1. and examples of some linguistic features of the most emblematic contact languages of these regions, European-based creoles, are discussed in the 3.2.

\section{1. An overview of contact settings and languages}


Some contact settings and outcomes such as the formation of European-based creoles are better described than others. The pre-Colombian period involved contact between Native American peoples in which some Amerindian languages served as linguae francae. Quechua, the language of the Incas, endures as a lingua franca in multiple locales and some of these varieties "may have originated as pidginized varieties of an Inca trade language, for example Ecuadorian Quechua" (Versteegh 2008: 172). The related languages Tupi and Guarani came to be widely used by speakers of other languages in the Amazon area. Cocama possibly arose as a Tupi-based creole in the 15th century from contact between Tupi and Arawakan speakers, drawing on an older Quechua-based pidgin (Eriksen \& Galucio 2014: 191). Nheengatu (Língua Geral), another Tupi lingua franca, arose by the 17th century from intense contact with Portuguese colonizers. Meira \& Muysken (2017: 205) argue that Carib Coastal Pidgin or Coastal Karinya Pidgin (a likely source for Island Carib creole) was the main pidgin language on the northern Coast of South America and in the Guiana region, used first between Arawak and Kariña speakers, but then extended to French contacts, and finally with the Wayana and Aluku/Boni Marrons further inland. Further south, Mapudungun served as a lingua franca for parts of Chile and the Pampas under the expansion of the Mapuche from the 17th to 19th centuries (Operé 2008: 65).

The foregoing shows that some languages that initially served inter-Amerindian contacts were later extended to contacts with Europeans, with new contact languages developing from the new linguistic landscape. One of these is Media Lengua, an intricate mixture of Spanish and Quechua spoken in Ecuador (Muysken 2013). Several trade pidgins lexified by Spanish also arose in the 18th and 19th centuries in the Ecuadoran Upper Amazon, such as Pioje Pidgin Spanish (Muysken 1980), which had SOV word order, drew basic pronouns from the possessive, and used the gerund as the main form of the verb. Nambikwara-Portuguese Pidgin in the early 20th century facilitated communication between 
Nambikwara Indians and Brazilian government workers employed along the telegraph lines (Lévi-Strauss 1955). A further example is Patagonian Jargon Spanish, a trade jargon used between the Tehuelche and the British, Americans, French, and Spanish engaged in the sealing and whaling industries in the late 18th and early 19th centuries (Roberts 2014).

With the onset of the plantation economy in the Caribbean and parts of South America, which involved large populations of enslaved Africans working on Europeanowned sugar plantations, European-based creole languages emerged out of the contact between various European languages (Dutch, English, French, Spanish) as spoken by European owners and overseers, and African languages spoken by the displaced populations. While they involve lexical items mostly derived from these European languages, their structures often do not at all or only partially match those of the European languages. In some cases, they show various degrees of structural resemblances to the (African) languages of their creators or are different from both, see Section 4. These languages are still widely used across the Caribbean and South American region and some of them, such as Jamaican and other English-based creoles were also transplanted to other areas in Central America, such as Costa Rica, Panama and Nicaragua, where they spurred the development of new contact varieties. They function as unofficial national languages in most countries as they were also acquired by other population groups after the end of slavery. Creole languages, especially those spoken by Maroon populations, also entered into contact with Amerindian languages due to economic contacts between their speakers and gave rise to new mixed languages such as the Trio-Ndyuka Pidgin (Huttar \& Velantie 1997; Meira \& Muysken 2017) from Suriname and the Wayana-Aluku Pidgin (Dupuy 2007) from French Guiana. In addition, there is Garifuna spoken in Belize which combines Arawak with lexical material from Carib and European languages (Escure 2004). 
In the post-slavery period when Asian labourers were brought in to replace enslaved Africans on the plantations, Asian languages came into contact with creole languages and European languages in some countries (such as Javanese in Suriname and Bhojpuri in Guyana, Trinidad, and Suriname), giving rise to localized or simplified Asian varieties (Mohan 1990; Yakpo 2017b; Villerius 2017; Rojas-Berscia \& Shi 2017). However, processes of language shift towards local creole languages and ex-colonial European languages are often leading to the decline of these languages.

Another kind of contact language formation involves convergence between an existing creole and a European language that was not involved in the creole's original formation. A case in point is the vernacular English of St. Lucia which arose through contact with Kwéyòl, the local French-lexifier creole (Garrett 2003), and English, the new official language. Also, postcolonial education systems, migration, and mass media have brought socially separated groups and/or languages in closer touch with each other such as Haitians, Guyanese and Brazilians with Surinamese Maroons (Migge \& Léglise 2013) and speakers of Sranami, an Indic contact language, with Suriname's national language Sranan Tongo (Yakpo 2017b). These contact processes have brought about new creole varieties that serve as lingua franca and show various types of contact-induced changes. Postcolonial contact settings have also induced the emergence of new varieties of European ex-colonial languages (see Deuber 2014; Lacoste 2017 on English; Chaudenson 1998; Léglise 2003 on French, de Kleine 2007; Muysken 2017 on Dutch, and Lipski 2005 on Spanish varieties) and new creole varieties (Borges 2017; Migge \& Léglise 2013; Yakpo 2017a).

In addition, intra-regional migration (occasionally dating back to colonial times) has also altered contact patterns in all of the countries of the three broad regions. For instance, Mestizos from northern America and other Central American countries moved to Belize in the 19th century and therefore Mestizo varieties of Spanish came into contact with Belize 
Creole and English. Another case involved the migration of Haitians to both Caribbean and South American countries due to natural disasters and political changes in Haiti. As a result, Haitian Creole has come in contact with other languages, including other (French) Creoles and French in French Guiana and Sranan and Maroon Creoles in Suriname and French Guiana (Laëthier 2011). The French state settled Hmongs from Loas in French Guiana in the 1970s following the Indo-Chinese war. Varieties of Hmong have thus come into contact with Nengee, French, and French Guianese Creole - speakers have adopted lexical items from these languages (Ly 2007).

A non-exhaustive overview of the different kinds of languages that have emerged from these contact patterns follows below. The linguistic outcomes best described in the literature are the creoles languages of the Caribbean and the Guyana region.

\section{Native American trade pidgins}

Carib Coastal Pidgin or Coastal Karinya Pidgin (Northern Coast of South America and Guiana region, Meira \& Muysken 2017)

Nheengatu (Brazil, Moore et al. 1994)

\section{Contact languages involving Native American languages \& colonizer's languages}

Media Lengua (Ecuador, Muysken 2013)

Nambikwara-Portuguese Pidgin (Brazil, Lévi-Strauss 1955)

Piñaguero Panare Pidgin Spanish (Venezuela, Riley 1952)

Pioje Pidgin Spanish (Ecuador, Simson 1879; Muysken 1980)

Patagonian Jargon Spanish (Argentina, Roberts 2014)

\section{Creoles}




\section{Dutch-lexified Creoles}

Berbice Dutch (Guyana, Kouwenberg 2013a)

Virgin Islands Dutch Creole (Sabino 2012)

\section{English-lexified Creoles}

Bahamian (Bahamas, Hackert 2013)

Belizian (Belize, Escure 2013a)

Creolese (Guyana, Devonish \& Thompson 2013)

Jamaican (Jamaica, Farquharson 2013)

Limón Creole (Costa Rica, Herzfeld 1978)

Miskito or Nicaraguan Creole English (Nicaragua, Bartens 2013a)

Nenge(e) or Eastern Maroon Creole (Suriname \& French Guiana, Migge 2013a)

Saamaka (Suriname, Aboh et al. 2013)

San Andres Creole (Columbia, Bartens 2013b)

Sranan (Suriname, Winford \& Plag 2013)

Vincentian (St Vincent \& the Grenadines, Prescod 2015)

Vernacular English (St Lucia, Garrett 2003)

\section{French-lexified Creoles}

Guadeloupean \& Martinican (Colot \& Ludwig 2013b)

Guianese (French Guiana, Pfänder 2013)

Haitian (Haiti, Fattier 2013a)

Kheuól or Karipuna French Creole (Brazil, Tobler 1983)

Kwéyòl (St Lucia, Carrington 1984) 
Spanish/Portuguese-lexified Creoles

Papiamento/u (Aruba, Bonnaire, and Curaçao, Maurer 2013)

Palenquero (Colombia, Schwegler 2013)

Panamanian Afro-Hispanic Creole (Panama, Lipski 1986)

\section{Native American - creoles Pidgins}

Ndyuka-Trio Pidgin (Suriname, Huttar \& Velantie 1997)

\section{Indigenized Asian languages}

Boshpuri (Trinidad, Mohan 1990)

Sranami (Suriname, Yakpo 2017b)

Surinamese Javanese (Suriname, Villerius 2017)

Suriname Hakka (Suriname, Rojas-Berscia \& Shi 2017)

\section{New varieties of Creoles}

Urban (L1 \& L2) Nengee (French Guiana, Migge \& Léglise 2013)

Urban Sranan Tongo (Suriname, Yakpo 2017a)

\section{New/indigenized or localized Varieties of European languages}

Suriname Dutch (Suriname, de Kleine 2007)

Caribbean Englishes (Lacoste 2017; Winford 1991)

Caribbean French (French Guiana, Léglise 2003)

Afro-Peruvian Spanish (Peru, Sessarego 2015)

Afro-Bolivian Spanish/ Afro-Yungueño Spanish (Bolivia, Lipski 2008; Perez 2015;

Sessarego 2009) 
Afro-Hispanic (Americas, Lipski 2005)

\section{2. Shared linguistic features of Caribbean Creoles and other contact languages}

Research has traditionally focused on English-lexified Creoles and on morphosyntax, and much less attention has been paid to other areas of grammar such as phonetics and phonology (Smith 2008) and semantics or pragmatics. Substantial descriptions of individual languages and comparative overviews of a wide range of pidgins and creoles can be found in Holm \& Patrick (2001a) and in Michaelis et al. (2013a, 2013b). Here I only discuss a few features that have figured prominently. One feature that has received a lot of attention is the copula domain, particularly in English-based creoles. Unlike European languages, English-based Caribbean creoles distinguish predicate nominals and possessives from locatives and attributives. Attributive predicative structures do not involve a copula clause because property items are verbs in the English-based Creoles (Michaelis \& APiCs Consortium 2013a: 295), as in (1).

(1) Dis Guatemala kweson me $\varnothing$ kajinda hat. (Belizian Creole)

DEM Guatemala question ANT COP kind.of hot

'This Guatemala question was rather hot.' (Escure 2013a: 96)

Predicate nominals and possessives require a copula, often $n a$ or $d a$ (which shares its form with the focus marker) that is generally not fully verbal and the construction has a topiccomment construction (2).

(2) Di djadj $n$ di dakta da gud fren. (Belizian Creole)

DET judge and DET doctor COP good friend 
'The judge and the doctor are good friends.' (Escure 2013b: 9-139)

Predicative locative and existential constructions generally also involve a copula, $d e$ or $d \varepsilon$, which is verbal (3).

(3) Bra fayaflay $d \varepsilon$ da staan bra Anansi $d \varepsilon$ da bo.

Brother Firefly COP at stern brother Anansi COP at bow

'Brother Firefly was at the stern and brother Anansi was at the bow.' (Escure 2013b:

9-144)

The exact details differ somewhat between creoles. For instance, in some varieties such as

Belizian Creole, there is variation in copular absence in nominal and locative contexts

(Escure 1982; Migge 1996):

(4) Krab $\varnothing \quad$ way in. (Belizian Creole)

Crab COP way in

'Crabs are way in. OR: Crabs burry themselves deep (in the sand).' (Escure 2013b: 9-

144)

In the Surinamese Creoles this is not attested (Arends 1986). In Nengee equative and class nominal constructions are not distinguished while in others, such as Saamaka and earlier Sranan Tongo, they are differentiated (Arends 1986; McWhorter \& Good 2012). Note also that the predicative nominal construction may be replaced by the copular used in locative contexts in non-present tense constructions. 
The copular domain is structured differently in non-English-based creoles. In Frenchbased Caribbean creoles such as Guadeloupean Creole all three structures do not involve a copular element:

(5) Diana $\varnothing \quad$ bèl. $\quad$ (Guadeloupean Creole)

Diana COP beautiful

'Diana is beautiful.' (Colot \& Ludwig 2013a: 50-139)

(6) $\quad$ I $\quad$ dòktè.

3 sg COP doctor

'He/she is a doctor.' (Colot \& Ludwig 2013a: 50-141)

(7) I $\varnothing$ anlè pon-la.

3SG COP on bridge-DEF

'He/she is on the bridge.' (Colot \& Ludwig 2013a: 50-142)

In contrast, Papiamentu, a Spanish-based language, has an obligatory invariant copula ta in all three constructions (Michaelis \& APiCs Consortium 2013b: 302).

(8) E ta mashá bunita mes. (Papiamentu)

3SG COP much pretty EMPH

'It is really very pretty.' (Kouwenberg 2013b: 47-149)

(9) E ta un muhé chikitu.

3SG COP INDF woman small

'She is a small woman.' (Kouwenberg 2013b: 47-147)

(10) Ora mi ta na lama mi ta siña landa, [...]

Hour 1SG COP LOC sea 1SG IMPFV learn swim 
The Trio-Ndyuka pidgin spoken in Suriname resembles French-based creoles in that it does not involve a copula in any of the three constructions:

\author{
(11) tide $\varnothing \quad$ tuna munu (Trio-Ndyuka Pidgin) \\ now/today COP river big, high \\ 'the river is high now.' (Meira \& Muysken 2017: 215)
}

Another area that has been studied intensely is the tense, mood and aspect (TMA) system.1 "In the Atlantic Creoles [including the Caribbean and West Africa], verbs generally indicate tense and aspect not with inflections but rather with preverbal (in some cases postverbal) markers.” (Holm \& Patrick 2001: vii). Creoles in the Caribbean region generally have a relative past marker derived from English been (bin, bi, be, ben, $m i$ ) in the case of English-based creoles (12) and the French past participle été (té) in French-based creoles (13) to mark anterior tense and these particles can be combined with aspectual markers. The anterior marker is also widely used to mark the counterfactual in if-clauses.
(12) I ha dis man bin a wuhk lan fo J. (St Vincentian Creole) 3SG have DEM man ANT PROG work land for J. 'He had two sheep.' (Prescod 2013: 7-9)
(13) Mwen te konn vann liv bò lekòl la. (Haitian Creole) 1SG ANT HAB sell book close school DEF 'I used to sell books close to the school.' (Fattier 2013b: 49-130)


However, past is most commonly expressed via the unmarked verb in the case of dynamic verbs (14-15).

(14) I posh evriting duhng. (St Vincentian Creole)

1SG push everything down

'I pushed everything down.' (Prescod 2013: 7-136)

(15) Bouki vann chat la. (Haitian Creole)

Bouki sell cat DET

'Bouki sold the cat.' (Fattier 2013b: 49-146)

Papiamentu has an imperfective past tense marker tabata which may be combined with modal forms (Kouwenberg 2013b), (16). However, unmarked forms are only possible for a subset of stative verbs, namely those which cannot be combined with the progressive marker. Entirely unmarked dynamic verbs with an anterior interpretation do not seem to exist.

(16) E tabata sa bini seka nos tur día. (Papiamentu)

3SG ANT able come at 1PL every day

'He came by us every day.' (Kouwenberg 2013b: 47-88)

The Trio-Ndyuka Pidgin does not appear to have any TAM marking.

(17) mi-ponoh-tz-ne (Trio-Ndyuka Pidgin)

2SG-tell-pl-pa.DIST

'you all told a story (long ago).' $\quad$ (Meira \& Muysken 2017: 212) 
In many varieties there is a progressive marker which may perform either only progressive functions or progressive, habitual, current state and in some cases also future. In Englishbased creoles in the region the marker is either $a$ or a form of $d e(d e, d i, e),(18-19)$. Copula de derives from the English locative there as in the case of the locative copular and $a$ originates with the English dialectal form $a V$-ing.

$\begin{array}{llll}H i & a & k u h m & \text { tomaaro. (St Vincentian Creole) } \\ \text { he IMPFV come tomorrow }\end{array}$

'He's coming tomorrow.' (Prescod 2013: 7-127)

(19) Dem a bil aaroroot faktori now. (St Vincentian Creole)

3PL PROG build arrowroot factory now

'They are building an arrowroot factory now.' (Prescod 2013: 7-125)

In French-based creoles, the progressive form is either $k a$ as in Antillean creoles or ape < French après as in Haitian. While it is mainly used to mark progressive aspect and future in Haitian (DeGraff 2001: 104), it can also encode habitual and current state in Guadeloupean (20-21).

(20) I $\quad \mathrm{ka}$ dòmi. (Guadeloupean)

3SG PROG sleep

'He/she is sleeping.' (Colot \& Ludwig 2013a: 50-79)

(21) I ka jwé foutbòl.

3SG HAB play football

'He plays football.' (Colot \& Ludwig 2013a: 50-81) 
In Papiamentu the preverbal $t a$ can express a wide range of meanings including, habitual, current state, progressive and future (22). It can also be combined with the Spanish verbal suffix - $n d o$.

(22) E baka ta kome yerba; [...] (Papiamentu)
DEF cow PROG eat grass

'The cow is eating grass.' (Kouwenberg 2013b: 47-43)

Serial verb constructions (SVCs) constitute another area of interest in research on creoles. They involve two or more verbs in sequence where one of them, usually the second one, has a functional meaning. There are different types and creoles differ in terms of the variety of SVCs and the kinds of grammatical functions that they perform (see Winford 1993). One type that is commonly found are SVCs involving the reflexes of the verbs go and come which function as directional markers expressing 'away from a point of reference to' and 'from a point of reference to', respectively.

(22) A subi go anda. (Nengee/Eastern Maroon Creole) he climb DIR over.there 'He climbed over there.' (Migge 2013b: 4-143)

(23) An voyéy alé Lapwent. (Guadeloupean Creole) 1SG send.3SG go Pointe-à-Pitre 'I sent it to Pointe-à-Pitre.' (Colot \& Ludwig 2013a: 50-157)

(24) E bebi a gatia bai den kushina. (Papiamentu) 
DEF baby IMPFV creep go in kitchen

'The baby crept into the kitchen.' (Kouwenberg 2013b: 47-164)

\section{CREOLE GENESIS}

The topic that has dominated $\mathrm{P} / \mathrm{C}$ studies more than any other are the circumstances of $\mathrm{P} / \mathrm{C}$ formation. The Bioprogram Hypothesis (LBH, Bickerton 1984), along with its numerous challenges by specialists, was a major driver of genesis research. The LBH posits that creole formation constitutes a special case of first language acquisition, with children in plantation societies activating an innate blueprint for language in the face of inadequate input (a structurally reduced pidgin spoken by their parents) in order to create a full, native language. Caribbean and South American P/Cs have figured prominently in responses to the LBH because plantation economies played a crucial role in the emergence of many creoles in the region. However, sociohistorical research which initially focusing predominantly on demography (e.g. ratios of enslaved Africans versus Europeans, African versus locally-born slaves, and children versus adults), has revealed that plantations differed demographically and consequently gave rise to different linguistic outcomes.

For instance, the Suriname and Haiti contexts were initially characterized by low enslaved versus European and African versus locally-born slave ratios, giving newly arriving enslaved Africans little sustained contact with the lexifier or dominant European language (Arends 1995; Singler 1995). The resulting languages (Suriname Creoles and Haitian Creole) are consequently highly distinct from their lexifiers in phonology and morphosyntax. Moreover, the small number of children and "the rate at which the proportion of locally-born blacks to African-born blacks changed in favor of the former, was so slow that it seems highly unlikely that creolization" (Arends \& Bruyn 1995: 112) understood as nativization would have been instantaneous. On the other end of the spectrum, there were colonies whose 
demographic conditions allowed enslaved labour greater access to European languages. These contexts produced varieties with greater structural overlap with their European input languages such as the creoles of the French Antilles and Barbados (Singler 1995; Rickford \& Handler 1994). Other locales such as Bequia (Walker \& Meyerhoff 2015) and Saban (Williams \& Myrick 2015) did not involve plantation economies and produced non-creole varieties of English or Spanish (Sessarego 2015).

More recent research delves into the nature of life on plantations and in early communities using available qualitative and quantitative data. Arends' (2017: 35-53) analysis of historical sources on the Guyana region shows that a dense network of overlapping European and particularly English settlements existed in pre-1650 Suriname which suggests that the plantation varieties probably emerged prior to 1650 or that these varieties had a strong impact on their emergence. His analysis of the makeup of the $18^{\text {th }}$ century plantation population (Arends 2017: 101-121) also demonstrates that it was highly stratified on the basis of ethnicity (African, European, Creole) but also occupation, creating a diverse community consisting of a number of status groups (e.g. skilled labourers, domestic staff, children and older people, field hand, overseers) with partially different social and linguistic practices whose importance also shifted over time. Instead of strict social separation, there also existed rich and dynamic relationships across racial lines between these different groupings and with people from others plantations and from outside of the planation context (e.g. soldiers, Maroons, city dweller). This suggests that creole genesis and development was by no means abrupt or unidirectional, but involved socially and linguistically complex processes, as in other contact settings, taking place in dynamic and overlapping contact settings.

The contribution of the languages of the creators of creoles, so-called substrate influence, has played a central role in genesis research and has inspired a number of collections (e.g. Migge \& Smith 2007; Michaelis 2008; Lefebvre 2011; Essegbey et al. 2013; 
Muysken \& Smith 2015) and articles ranging from comparisons of specific aspects of grammar in African input languages such as the varieties of Gbe and in Caribbean/South American creoles (e.g. Haitian, Suriname Creoles, Palenque, Berbice Dutch) to theoretical discussions assessing the workings of first language input (Singler 1988; Winford 2003).2 While all of this research highlights the importance of the first languages of the creators of creoles in creole formation, theories posit different roles and processes. Strong versions, such as the Relexification Hypothesis (Lefebvre 1998), maintain that creoles are essentially continuations of their creators' first languages and that their genesis was a cognitive process. Weaker, socially-oriented versions (Alleyne 1971, 1980; Keesing 1988, Migge \& Goury 2008) argue that the impact of different first languages was not uniform across contexts and areas of grammar since other sources (e.g. superstrate, universals), factors (e.g. social context, types of languages) and processes also contributed to the shaping of creole grammars. The Relexification Hypothesis also differs from other substrate accounts in that it proposes that creators adopted phonetic strings (words) from the superstrate and imposed them on lexical entries of their first languages. This process used to be referred to as relexification but is now called relabelling (Lefebvre 2015). It is supported by levelling which helps to address differences between substrate grammars. Other substrate accounts generally posit a more dynamic interaction between substrates and other sources and processes. They generally start from the assumption that creole genesis involves processes that are part of second language learning (e.g. see summary in Winford 2003; Siegel 2008).

The bulk of substrate research has assessed morphosyntactic features such as copulas, SVCs, TMA systems, and complementation, as these figure prominently in the LBH. Migge (2003: 90ff), for instance, shows on the basis of contemporary language data that there are similarities in terms of the types of SVCs (e.g. directional, dative) and their makeup between the creoles of Suriname and their main African input languages, varieties of Gbe. Example 
(25), for example, demonstrates that both languages have an element that is homophonous with the verb 'to go', go in the Eastern Maroon Creole and yi in Aja Gbe, which is used to introduce a locational phrase to a main verb, indicating that the movement denoted by the main verb is away from the point of reference towards some other location. They also have very similar syntactic properties.

a. Nownow, den ná man post $i$ go a foto moo. (EMC, PM 17) now they NEG able send 2SG SV LOC town more

'Now, they cannot send you back to Paramaribo anymore.'

b. $Y \varepsilon \quad a \quad m \supset$ o tro $\varepsilon$ hen yi axwe. (Gbe, Aja 1)

3SG FUT say 2SG return 3SG hold SV house

'He'll tell you to bring it back to the house.' (Migge 2003: 92)

There are also substantial similarities between Suriname creoles and Gbe languages in the copular domain. In both groups of languages, property items are mostly verbs and nominal and locational structures require different linking elements (see also above). Predicative nominal constructions are widely expressed as topic-comment constructions where the predicating or linking element is a focus or presentative marker (Migge 2002: 73ff). With respect to the linking element used in locational constructions, Migge (2003: 64-69) shows that the Gbe (la, $d o / q u, l e)$ and Surinamese $(d e)$ forms are verbal and can be used to predicate a range of elements such as locational phrases (26), reduplicated adjectives and ideophones (27), and also express existence without a complement (28). Notwithstanding some distributional differences, the similarities suggest that the Surinamese copula domain and its elements were modeled on that in Gbe languages. 
(26) a. $A$ be de na Alibina wan pisi ten. (EMC, ND 4b) 3SG ANT COP LOC Albina one piece time

'He was in Alibina for some time.'

b. Ixhe mo de do me kliya. (Gbe, Xwela 1)

fish PAST COP net in IDEO

'Fish were in the net in great quantity.'

(27) a. Ma ala en ede be de baakabaaka. (EMC, PM 11b)

but all 3SG head PAST COP blackblack

'But all his head (hair) was still (in a) black (state).'

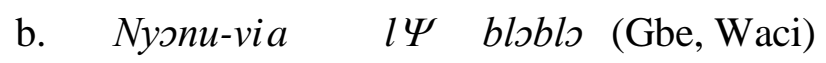

woman-small DET COP thinthin

'The girl is (still in a) thin (state).'

(28) a. $A$ goon mu de, a honiman mu de. (EMC, ND 3a) DET field must COP DET hunter must COP

'There must be a field and there must be a hunter (man).'

b. A: Degbo do? B: $\Psi$ li. (Gbe, Waci) name $\quad$ COP? $\quad 3 \mathrm{SG} \quad \mathrm{COP}$

‘A: How about Degbe? B: He is well.' (Migge 2003: 65-67)

More recently, other phenomena, including lexico-semantics (Schwegler 2000; Huttar et al. 2007), morphological processes (Kouwenberg 2003), and phonology (Smith 2008), have also figured in substrate research. This research took its initial cue from Alleyne (1980) and Keesing's (1988) work on Melanesian P/Cs (see Meakins, this volume). Studies confirm the important role that substrate languages have played in creole formation in general and the West African languages Gbe, Akan, and Kikongo in the case of Creoles from the Americas 
and the Caribbean. But much of this work also demonstrates that creoles are not direct copies of their substrates because their genesis also involved the influence of European languages, other L1s, universals, and processes of language change. Debate on the processes that shape the formation of creoles still continues unabated.

Most recently a rather contentious debate has arisen between some researchers about the place of simplification in creole genesis. McWhorter (2002) and others such as Parkvall (2008) see the pidgin-creole life-cycle and processes of simplification and pidginization as definitive of creole genesis because, in their view, creoles developed from highly reduced contact vernaculars. Their creators' first languages and superstrates impacted creole grammars but only simplified or less complex features were taken over to facilitate communication in multilingual contact areas. As a result, creoles constitute a separate set of languages whose members are bearers of three features indicative of earlier pidginization: contextual inflection such as concord marking, functional tone marking and semantically opaque morphology (McWhorter 2018). The findings from recent phylogenetic research (Bakker et al. 2017) are seen as evidence in favor of this hypothesis. This view of creole exceptionalism is vehemently opposed by scholars such as DeGraff (2005) and Mufwene (2008), among others. They reject the crucial role of simplification and pidginization in creole genesis and thus the exceptional status of creoles as a separate group of languages, arguing that the processes that gave rise to creoles also commonly occur in other contact settings.

There is also debate over whether New World P/Cs originated in Africa (Hancock 1986; McWhorter 1999, 2000; Devonish 2002; Smith 2015) or developed in the Americas and whether they were diffused or transplanted from one location such as the Upper Guinea Coast (Hancock) or the Gold Coast (McWhorter) in West Africa, or St Kitts in the Caribbean (Baker 1999; Baker \& Bruyn 1999), or whether they largely developed separately in each 
territory. There is also debate about the relative importance of diffusion and the kinds of elements that were diffused across regions and territories. Was it mostly restricted to a set of lexical features or did it possibly involve entire varieties or subsystems thereof? There is need to broaden the types of features (e.g. pragmatics), data (elicited examples versus textual data) and the types of creoles. For instance, substrate influence in French-based creoles in the Caribbean and South America (e.g. Jenkins \& Pfänder 2018 on French Guianese Creole) is still in its infancy because French research has traditionally focused on the French superstrate and often denied the role of substrate influence (Chaudenson 2001: 93-4). Most of the descriptive research on Caribbean/South American creoles came about due to interest in their origins and development.

The focus on synchronic data to study the formation of creoles was rightly criticised by Arends (2002) who was one of the pioneers for research on historical texts written in Caribbean/South America creoles. Scholars (e.g. Winer 1984; Arends and Perl 1995; Baker \& Bruyn 1999) search for and edit a range of older texts (e.g. letter, manuals, court records, dictionaries) and mine them for linguistic details and for information on the social and sociolinguistic makeup of the contexts in which creoles developed e.g. (Grant 1999; Arends 2017). One particularly notable effort in this regard is the collective volume edited by Baker \& Bruyn (1999) which examines the largest body of early texts (two books and a newspapers) on Caribbean creoles by one author, Samuel Augustus Mathews, from a variety of angles in order to gain insights into the origin and diffusion of Caribbean creoles, and the place of St. Kitts in these processes.

One obvious problem with early texts is that they were often not written by native speakers of these languages. Arends' (2017) research on the authors of early Sranan texts, however, shows that many of the authors such as European missionaries and colonial government agents were competent in the language. However, Migge and van den Berg 
(2009) also show that some of the features such as the imperfective marker in the early Sranan texts involves patterns of variation (between presence and absence of $e$ ) that are very similar to those found in contemporary second language varieties of the Eastern Maroon varieties spoken in French Guiana. This suggests that second language practices affected the development of some areas of grammar in the plantation creoles. Another issue is the relative paucity of such texts for some periods, particularly the earliest period, and for some contexts. Historical texts have been studied for the Surinamese Creoles Sranan and Saamaka (e.g. Arends 1989; Bruyn 1995; van den Berg 2007), Haiti (Carden \& Stewart 1988), Jamaica (Lalla and D’Costa 1990), Dutch Creole (van Rossem \& van der Voort 1996; Sabino 2012), French Antillean Creoles (Hazaël-Massieux 1996).

Philological research, like demographic investigation, supports a gradualist model of creole genesis which, in a nutshell, posits that creole genesis was not an instantaneous, abrupt or uniform process, as maintained by Bickerton (1984), but took place over several generations. It shows that variation was common and occurred along several dimensions (geographical, social, ethic) and also changed over time (e.g. van den Berg 2007: 379-392; Arends 2017: chapter 4). Several areas of the morphosyntax underwent changes after what must have been the original emergence of a creole language. Arends \& Bruyn (1995: 113), for instance, show that after 1800 "a monolithic category of equation (including attribution and identification, both expressed by $d a)$ " (29-30) became differentiated into two subcategories: copula $d a$ came to be used for identification (31) and copula de for attribution (32).

$\begin{array}{llll}\text { Hoe fassi joe man da granman } & \text { vo joe? } \\ \text { What way 2SG man COP boss } & \text { of } 2 \mathrm{SG} \\ \text { 'Your husband doesn't own you, does he?' } & \text { (attr.; Van Dyk c1765: 69) }\end{array}$


Mie no sabie o sama da em.

1SG NEG know what person COP 3SG

'I don't know who he is.'

(indent.: Weygandt 1978: 91)

(31) Mi wefi de wan bejari soema toe.

1SG wife COP a aged person also

'My wife is [an] old [person] too,'

(attr.; Anon. 1829: 8)

Mi da Gabriel, disi de tanapoe na Gado fesi alarem.

1SG COP Gabriel REL ASP stand LOC God face always

'I am Gabriel, who is always standing before God.' (ident.; Anon 1829: 8)

(Examples come from Arends \& Bruyn (1995: 113).

As in the case of other languages, changes in grammar were motivated by language internal and contact-induced change. The latter probably occurred due to changes in the speaker populations such as in the case where enslaved Africans whose language backgrounds differed from that of the original creators learned the plantation varieties and introduced new features. The introduction of new lexical items often happened due to changes in the slave owner or overseer group (van den Berg 2007: 393-4). In the case of possible outcomes of internal changes such as grammaticalization, Bruyn (1996: 39) cautions that "they may differ from ordinary grammaticalization in languages with a longer history: they may proceed at a higher rate and they may be crucially determined by influences from other languages." For example, the development of $18^{\text {th }}$ century definite determiner $d a<$ English 'that' in Sranan is a case of regular language-internal grammaticalization in that it "increased in frequency, lost some of its deictic value, and has been reduced in form, via $n a$ to $a$ " (ibid). In contrast, no such developments are attested in the sources for the indefinite determiner wan < English 'one', suggesting that this usage dates from the early stages of Sranan's development and was 
based on a model from one of the input languages. Bruyn (1996) identifies a number of such instances (e.g. dative serial verb gi and complementizer taki in Sranan) and proposes to refer to them as instances of apparent grammaticalization, that is instances "where a feature does not result from grammaticalization that took place within the Creole language itself but rather from the transfer of the result of a process of grammaticalization that has taken place in another language" (p. 42). Change may also be due to quantitative social changes when the creole varieties of the enslaved became more socially prominent than those of their enslavers leading to a reduction in frequency or loss of the latter's (original) practices, and thus their representation in written documents (van den Berg 2007).

\section{The Sociolinguistics of the Caribbean}

Sociolinguistic research played an important role in early research on (Caribbean) creoles because many early investigators were trained in what was then a rapidly growing field (Rickford 1988; Meyerhoff, this volume). The Caribbean (particularly the English-official countries) thus largely became the birth cradle of P/C-based models of variation and furnished the bulk of empirical evidence on variation in $\mathrm{P} / \mathrm{Cs}$, which also generated insights into important notions in (quantitative) sociolinguistics such as social class (Rickford 1986).3

The most prominently discussed $\mathrm{P} / \mathrm{C}$ model of variation (which is often assumed to represent the sociolinguistic structure of creoles) is the Post-Creole Continuum. Although the notion of a continuum was already discussed in the 1960s (see Holm 1988: 52-56), the concept of the Post-Creole Continuum is generally associated with DeCamp's (1971) discussion of the Jamaican situation and Bickerton's (1975) analysis of recorded data from Guyana. The model posits that an English-lexified creole and a local variety of Standard English constitute two poles of a single system with continuous variation between them. It allegedly emerged after the end of slavery when speakers of the deep creole, also referred to 
as the basilect, gained greater access to English, the so-called acrolect, for the purpose of social upward mobility. As people were learning English, they gradually replaced features in the deep creole with those derived from English, creating hybrid systems (called mesolects) drawing on both languages. The process leading to their formation was generally called decreolization, a term that implies that the basilect loses its distinct character through contact with the standard language. But subsequent quantitative research, as well as historical study, has deconstructed the notion of decreolization, showing that creoles are linguistically independent from their lexifiers and that the mesolect may not necessarily precede the basilect in creole development. What has been called decreolization involves contact-induced and internally-motivated language change, with social upward mobility and prestige being but one of the social motivations for change and contact between a creole and its lexifier being but one source of change (Aceto 1999; Bailey \& Maynor 1987; Rickford 1974; Winford 1997).

Ideologically the deep creole or basilect is traditionally associated with rural and informal contexts, and with speakers with lower educational achievements on account of the relative absence of higher educational institutions in rural areas. English meanwhile is indexically linked to education, urban areas, professional jobs and formal contexts (Rickford 1985). Quantitative sociolinguistic studies provided empirical evidence that linguistically distinguishable language systems co-exist in Caribbean communities and that their use is systematically conditioned by social factors as in all bilingual communities (Escure 1982; Edwards 1983; Rickford 1991; Devonish 1992). Belizean interviewees, for instance, mostly employ English variants of the copula (am, is, are, were, was) in formal contexts and creole equivalents $(d a, d e, \emptyset)$ in informal contexts (Young 1973; Escure 1982; Migge 1996). At the same time, stylistic variation within the sociolinguistic interview and across settings is nondiscrete, demonstrating that creole communities are not truly diglossic (Winford 1985). 
Interlocutors code-switch between varieties to negotiate interactional alignments, identities and relationships, as in all multilingual contexts. However, one 'system' usually dominates in a given interaction suggesting that it constitutes the matrix language of the interaction (Myers-Scotton 1993). Linguistic anthropological research on St Vincent (Abrahams 1983) also supports these findings.

Sociolinguistic research in the English-official Caribbean also successfully debunked the myth that all creole communities are structured the same way. Some communities such as Guyana and Jamaica (Rickford 1991; Edwards 1983; Patrick 1999) have two conventionalized creole varieties, a rural variety (i.e. basilect) and an urban variety which is linguistically intermediate between the rural variety and local English. However, it is a conventionalized variety and does not conform to DeCamp's (1971) notion of the mesolect as a zone of interaction. In other contexts, such as Belize, in contrast, there are two sets of conventionalized practices, English and creole, and the variation between them reflects codeswitching and/or ongoing language change (Young 1973; Migge 1986). In a third set of communities such as Trinidad, Barbados and the Bahamas, a deep creole variety is absent and the creole more closely resembles the Guyanese mesolect which shows closer affinity to standardized forms of English (Alleyne 1980; Winford 1997).

Finally, there are also contact settings such as Suriname, the ABC islands (Aruba, Bonaire, Curacaõ), and St Lucia and San Andrés where creoles co-exist with European languages of different lexical bases. The Post-Creole-Continuum is not relevant to these languages, as it was designed for contexts where a creole co-exists with its lexifier. Sociolinguistic research on the Eastern Maroon Creoles of Suriname and French Guiana (e.g. Migge \& Leglise 2013) shows that they have always had distinct stylistic registers that index social categories and identities. As the latter are affected by social change, both the social functions and linguistic forms that index them also undergo diachronic change and new 
practices linked to emerging social identities and categories arise. The impact of the dominant local languages is only one of the factors that drives language change.

In recent years, sociolinguistic research on Caribbean/South American creoles, like research in sociolinguistics more generally, has shifted to examining language use patterns and their meaning making potential (Mühleisen 2002). This research has also dealt with a wider range of varieties. The notion of face and linguistic politeness is at the center of various studies in Mühleisen \& Migge (2005). They show that variation does not simply respond to contextual factors but is actively deployed to negotiate social status, interactional and social identities and the functions of communicative routines. Other studies such as Rickford (2019b) and Sidnell (1999) show how semantic and pragmatic meanings impact the distribution of linguistic variants such as personal pronouns or explore gendered communicative norms (Sidnell 2003). Meyerhoff \& Walker (2007) investigate the impact of patterns of mobility on variation and Migge \& Leglise (2013) examine how migration affects language practices. There has also been work on the social meanings and functions of translingual practices (Shields-Brodber 1992; Youssef 1996). Migge (2015) in particular show that multilingual practices in French Guiana result from the acquisition of Eastern Maroon Creoles by diverse populations and the different social orientations of the younger population in the urban sphere. The latter deploys linguistically fuzzy practices as a distinct social strategy for managing social (especially ethnic) alignments and stigma. This meaningmaking approach to variation is in line with Le Page \& Tabouret-Keller's (1985) 'acts of identities' sociolinguistic model which was developed based on data from the English official Caribbean. It argues that "the individual creates for himself [/herself] the patterns of his [/her] linguistic behaviour so as to resemble those of the groups with which from time to time he [/she] wishes to be identified or so as to be unlike those from whom he [/she] wishes to be distinguished." (Le Page \& Tabouret-Keller 1985: 181). Identification is constrained, 
however, by aspects such as our ability to identify potential groups and our access to them and our ability to adapt our behaviour. However, the model was not widely adopted because instead of working from the social data, its categories were created based on linguistic data using cluster analysis, was not sufficiently constrained and did not take account of internal constraints (Rickford 2011).

Mediated linguistic practices among diaspora communities and non-traditional users are also rising. Managan (2011) explores enregistrement on Guadeloupean TV, that is the process by which a linguistic items or varieties become indexed with particular speaker groups or their attributes (Agha 2005). Garrett (2000) and Migge (2011) investigate the use of French Creole in St Lucian and the Eastern Maroon creoles in French Guianese radio programmes, respectively, Hinrichs (2006) and Moll (2015) explore computer-meditated practices and finally, there is also a growing tradition of research on language use in music (Herzfeld \& Moskowitz 2004; Farquharson 2017; Sankar and Winer 2006). The latter work is often linked to research on linguistic practices in Caribbean diaspora communities (e.g. Hinrichs 2014). These studies show that creole ways of speaking are dynamic, changing in step with their user communities, but continue to function as important meaning-making resources.

\section{CARIBBEAN CREOLES, EDUCATION AND STANDARDIZATION}

Due to the discrepancy between official language policies (and the ideologies motivating them) and actual language practices in creole-speaking communities, the use of P/Cs in education has been a persistent issue (see Angelo, Kennedy, this volume). Broadly speaking, governments typically mandate the ex-colonial language as the only means of instruction on all levels of education despite the fact that many children have little knowledge of that language upon entering school. The community languages spoken by children have 
traditionally been denigrated. With the growth of the school-attending population in recent decades, P/Cs are variously used by teachers to reduce educational failure.

However, such informal approaches used by educators have mostly focused on 'touching up' a colonial system designed for children who speak the ex-colonial language as their main language. For instance, P/C-speaking children are no longer punished for using their first languages on school premises and educational institutions are not permitted to openly denigrate them. Fundamental change such as implementation of the UN recommendation that children should be educated in their first language is still rarely considered as a viable option even if the $\mathrm{P} / \mathrm{C}$ is spoken by the majority. Full competence in the ex-colonial language remains one of the main goals of schooling.

Much of the research in the Caribbean has therefore focused on developing educational approaches that focus on clearly distinguishing $\mathrm{P} / \mathrm{C}$ practices from dominant language (English/French) practices and on mobilizing the former to enhance acquisition of the latter. On the basis of speech patterns in creole communities where P/Cs coexist with their lexifier (see section 4), Denis Craig $(1976,1999)$ has argued that Caribbean children should not be treated as speakers or learners of the dominant language because, due to the partial overlap between the two, the latter is neither a foreign language nor fully familiar to them; they often have good control of certain aspects of grammar (where the creole and the dominant language overlap) but lack competence in others and are often also not able to distinguish between creole and dominant language options in a socially appropriate manner because the social meanings of different options are not clear to them. This has generally negatively affected children's educational opportunities. Education must thus focus on clarifying the linguistic, stylistic and ideological differences between the languages involved and create instructional approaches that build on the overlaps in addition to raising the social profile of creoles. Pollard (1999) has further advocated for the greater use of creoles in some 
educational activities to unleash children's creative and expressive capacities. In short, educational institutions should pursue an additive rather than a subtractive model of education.

However traditional approaches focusing on acquisition of the dominant language generally only teach children literacy through the official variety of English, with the creole remaining an oral language in most domains - leaving intact inequalities in social prestige between the two. More recent approaches place greater emphasis on fostering concurrent competences in both languages; this involves the use of separate orthographic systems as well as teaching local cultural knowledge through the creole. Such methods are more readily accepted in contexts where the $\mathrm{P} / \mathrm{C}$ is recognized as a distinct language (Siegel 2006), including St Lucia, San Andres, the Eastern Maroon Creoles in French Guiana and Papiamentu/o in Aruba and Curacao (see papers in Migge et al. 2010). In cases where P/Cs serve as a (co-)medium of education, language planning has followed suit in developing orthographies, descriptive grammars, dictionaries, pedagogical materials, as well as new styles, practices, and terminologies. The French Antilles provides an instructive example of success in persistent language planning efforts; since the 1980s Jean Bernabé and other members of GEREC (Groupe d'études et de recherches en espace créolophone) brought about the standardization and acceptance of French-based creoles as subjects and media of education at school and university in France.

\section{CONCLUSION}

New World P/Cs have figured in almost all areas of research on P/Cs. Most of the theories and models that currently exist were based on or heavily influenced by P/Cs from this broad region. The preceding overview demonstrates that contexts, circumstances and outcomes were far from homogeneous and that academic models based on data from this region do not 
properly reflect the current state. Despite the dominance of the Caribbean, important gaps are still visible such as the fact that French-based creoles remain understudied or that much of the sociolinguistic and applied linguistic research has focused on contexts in which a P/C coexists with its lexifier. Future work will have to put greater emphasis on comparison within the three regions and beyond and across lexifiers.

\section{END NOTES}

1 For a useful overview of research on TMA systems in Creoles, see Winford (2018).

2 There is much less research on the nature of superstrate varieties, but see for example Chaudenson (1992), Smith (1987). Research confirms the importance of regional European varieties and also second language varieties as opposed to standard varieties.

3 For an overview of pertinent issues in quantitative sociolinguistics research on creoles and its contribution to research in quantitative sociolinguistics, as well as reprints of important articles by John Rickford, an important figure in the field, see Rickford (2019a).

\section{RELATED TOPICS}

The Typology of Pidgin and Creole Languages; The Atlantic; Sub-Saharan Africa; Australia and the South West Pacific; Creoles, Education and Policy; Diachronic Studies of Pidgins and Creoles

\section{FURTHER READING}

Farquharson, J. T. \& Migge, B. 2017. Pidgins and Creoles: Critical Concepts in Linguistics. Vols 1-4. Malden: Routledge. 
The three volumes reprint a wide range of prominent articles on sociolinguistics, genesis and applied research and provides succinct summaries of each area.

Kouwenberg, S. \& Singler, J. V. 2008. The Handbook of Pidgin and Creole Studies. Malden: Wiley-Blackwell.

This book consists of review articles that cover a wide range of topics in research on creoles.

Siegel, J. 2005. Applied Creolistics revisited. Journal of Pidgin and Creole Languages, 20(2): 293-323.

This article gives a state of the art on the implementation of creoles in a range of domains and the obstacles.

\section{REFERENCES}

Aboh, E. O., Smith, N. S. H. \& Veenstra, T. 2013. Saramaccan, in The Survey of Pidgin \& Creole Languages: English-based and Dutch-based Languages, Vol 1, edited by Susanne M. Michaelis, Philippe Maurer, Martin Haspelmath \& Magnus Huber. Oxford: Oxford University Press: 27-38.

Abrahams, R. D. 1983. The Man-of-Words in the West Indies. Performance and the Emergence of Creole Culture. Baltimore: Johns Hopkins University Press.

Aceto, M. 1999. Looking beyond Decreolization as an Explanatory Model of Language Change in Creole-Speaking Communities. Journal of Pidgin and Creole Languages, 14(1): 93-199. 
Agha, A. 2005. Voice, Footing, Enregisterment. Journal of Linguistic Anthropology, 15(1): $38-59$.

Alleyne, M. 1971. Acculturation and the Cultural Matrix of Creolization, in Pidginization and Creolization of Languages, edited by Dell Hymes. Cambridge: Cambridge University Press: $169-186$.

Alleyne, M. C. 1980. Comparative Afro-American: An Historical-Comparative Study of English-Based Afro-American Dialects of the New World. Ann Arbor: Karoma Publishers.

Archetti, E. A., Cammack, P. \& Roberts, B. 1987. Introduction, in Latin America, edited by Eduardo A. Archetti, Paul Cammack \& Bryan Roberts. New York: Monthly Review Press: xiii-xxiii.

Arends, J. 1986. Genesis and development of the equative copula in Sranan, in Substrata versus universals in creole genesis, edited by Pieter Muysken \& Norval Smith. Amsterdam: John Benjamins: 103-128.

Arends, J. 1989. Syntactic Developments in Sranan: Creolization as a Process. PhD dissertation, Radboud University Nijmegen.

Arends, J. 1995. Demographic Factors in the Formation of Sranan, in The Early Stages of Creolization, edited by Jacques Arends. Amsterdam: John Benjamins: 233-285.

Arends, J. 2002. The historical study of creoles and the future of creole studies, in Pidgin and Creole Linguistics in the Twenty-first Century, edited by Glenn Gilbert. New York: Peter Lang: 49-68.

Arends, J. 2017. Language and Slavery: A Social and Linguistic History of the Suriname creoles. Amsterdam: John Benjamins.

Arends, J. \& Bruyn, A. 1995. Gradualist and developmental hypotheses, in Pidgins and Creoles: an introduction, edited by Jacques Arends, Peter Muysken \& Norval Smith. Amsterdam: John Benjamins: 111-120. 
Arends, J. \& Perl, M. 1995. Early Suriname Creole Texts: A Collection of 18th-century Sranan and Saramaccan Documents. Frankfurt am Main: Vervuert.

Bailey, G. \& Maynor, N. 1987. Decreolization? Language in Society, 16(4): 449-474.

Baker, P. 1999. Investigating the origin and diffusion of shared features among the Atlantic English Creoles, in St. Kitts and the Atlantic Creoles: The Texts of Samuel Augustus Mathews in Perspective, edited by Phillip Baker \& Adrienne Bruyn. London: University of Westminster Press: 315-64.

Baker, P. \& Bruyn, A. 1999. St. Kitts and the Atlantic Creoles: The Texts of Samuel Augustus Mathews in Perspective. London: University of Westminster Press.

Bakewell, P. 1998. Colonial Latin America, in Latin America: Its Problems and Promise, edited by Jan Knippers Black. Boulder: Westview Press: 59-68.

Bakker, P., Borchsenius, F., Levisen, C. \& Sippola, E. 2017. Creole Studies-Phylogenetic Approaches. Amsterdam: John Benjamins.

Bartens, A. 2013a. Nicaraguan Creole English, in The Survey of Pidgin \& Creole Languages: English-based and Dutch-based Languages, Vol 1, edited by Susanne M. Michaelis, Philippe Maurer, Martin Haspelmath, \& Magnus Huber. Oxford: Oxford University Press: 115-126.

Bartens, A. 2013b. San Andres Creole English, in The Survey of Pidgin \& Creole Languages: English-based and Dutch-based Languages, Vol 1, edited by Susanne M. Michaelis, Philippe Maurer, Martin Haspelmath, \& Magnus Huber. Oxford: Oxford University Press: 101-114.

Bickerton, D. 1975. Dynamics of a Creole System. Cambridge: CUP.

Bickerton, D. 1984. The language bioprogram hypothesis. Behavioral and Brain Sciences, 7:173-221. 
Booth, J. A. \& Walker, T. W. 1993. The Central American Crisis, in Understanding Central America, edited by John A. Booth \& Thomas W. Walker. Boulder: Westview Press: 1-8.

Borges, R. 2017. The Maroon Creoles of the Guianas: Expansion, contact and hybridization, in Boundaries and Bridges: Language Contact in Multilingual Ecologies, edited by Kofi Yakpo \& Pieter Muysken. Berlin: Mouton de Gruyter: 87-128.

Bruyn, A. 1995. Grammaticalization in Creoles: The Development of Determiners and Relative Clauses in Sranan. Amsterdam: IFOTT.

Bruyn, A. 1996. On identifying instances of grammaticalization in Creole languages, in Changing Meanings, Changing Functions: Papers Relating to Grammaticalization in Contact Languages, edited by Phillip Baker \& Anead Syea. London: University of Westminster Press: 29-46.

Carden, G. \& Stewart, W. 1988. Binding theory, bioprogram, and creolization: Evidence from Haitian Creole. Journal of Pidgin and Creole Languages, 3(1): 1-67.

Carrington, L. D. 1984. St. Lucian Creole: A Descriptive Analysis of its Phonology and morphosyntax. Hamburg: H. Buske. (Kreolische Bibliothek, Vol. 6)

Chaudenson, R. 1992. Des Îles, des hommes, des langues. Paris: L'Harmattan.

Chaudenson, R. 1998. Variation, koïnéisation, créolisation: français d'Amérique et creoles, in Français d'Amérique. Variation, créolisation et normalization, edited by Patrice Brasseur. Centre des Etudes Canadiennes: 163-179.

Chaudenson, R. 2001. Creolization of language and culture. London: Routledge.

Colot, S. \& Ludwig, R. 2013a. Guadeloupean Creole structure data set, in Atlas of Pidgin and Creole Language Structures Online, edited by Susanne M. Michaelis, Philippe Maurer, Martin Haspelmath \& Magnus Huber. Leipzig: Max Planck Institute for Evolutionary Anthropology. (Available online at http://apics-online.info/contributions/50, Accessed on 2020-01-06.) 
Colot, S. \& Ludwig, R. 2013b. Guadeloupean Creole and Martinican Creole, in The Survey of Pidgin \& Creole Languages: Portuguese-based, Spanish-based and French-based Languages, Vol 2, edited by Susanne M. Michaelis, Philippe Maurer, Martin Haspelmath, \& Magnus Huber. Oxford: Oxford University Press: 205-219.

Craig, D. 1976. Bidialectal Education: Creole and standard in the West Indies. International Journal of the Sociology of Language, 8(1): 93-136.

Craig, D.1999. Teaching Language and Literacy: Policies and Procedures for Vernacular Situations. Georgetown, Guyana: Education and Development Services.

DeCamp, D. 1971. Towards a generative analysis of a post-Creole speech continuum, in Pidginization and Creolization of Languages, edited by Dell Hymes. Cambridge: Cambridge University Press: 349-70.

DeGraff, M. 2001. Kreyòl Ayisyen, or Haitian Creole (French Creole), in Comparative Creole Syntax, edited by John Holm \& Peter Patrick. London: Battlebridge: 101-126.

DeGraff, M. 2005. Linguists' most dangerous myth: The fallacy of Creole exceptionalism. Language in Society, 34(4): 533-591.

Deuber, D. 2014. English in the Caribbean: Variation, Style and Standards in Jamaica and Trinidad. Cambridge: Cambridge University Press.

Devonish, H. 1992. On the existence of autonomous language varieties, in Creole Continuum Situations, edited by Pauline Christie, Barbara Lalla, Velma Pollard \& Lawrence Carrington. Studies in Caribbean language II. SCL: University of West Indies Press: 1-12. Devonish, H. 2002. Talking Rhythm Stressing Tone: The Role of Prominence in Anglo-West African Creole Languages. Kingston: Arawak Publications.

Devonish, H. \& Thompson, D. 2013. Creolese, in The Survey of Pidgin \& Creole Languages: English-based and Dutch-based Languages, Vol 1, edited by Susanne M. Michaelis, 
Philippe Maurer, Martin Haspelmath, \& Magnus Huber. Oxford: Oxford University Press: 49-60.

Dupuy, F. 2007. Dynamiques interethniques dans le haut Maroni, in Pratiques et représentations linguistiques en Guyane: regards croisés, edited by Isabelle Léglise \& Bettina Migge. Paris: IRD: 107-117.

Edwards, W. 1983. Code selection and shifting in Guyana. Language and Society, 12(3): $295-311$.

Eltis, D. 2018. Methodology. (Accessed https://www.slavevoyages.org/voyage/about)

Eriksen, L. \& Galucio, A. V. 2014. The Tupian Expansion, in The Native Languages of South America: Origins, Development, Typology, edited by L. O’Connor and P. Muysken. Cambridge: Cambridge University Press: 177-199.

Escure, G. 1982. Contrastive patterns of intra-group and inter-group interaction in the creole continuum of Belize. Language in Society, 11(2): 239-264.

Escure, G. 2004. Garifuna in Belize and Honduras, in Creoles, Contact, and Language Change: Linguistic and social implications, edited by Geneviève Escure \& Armin Schwegler. Amsterdam: John Benjamins: 35-66.

Escure, G. 2013a. Belizean Creole, in The Survey of Pidgin \& Creole Languages: Englishbased and Dutch-based Languages, Vol 1, edited by Susanne M. Michaelis, Philippe Maurer, Martin Haspelmath, \& Magnus Huber. Oxford: Oxford University Press: 92-100. Escure, G. 2013b. Belizean Creole structure dataset, in Atlas of Pidgin and Creole Language Structures Online, edited by Susanne M. Michaelis, Philippe Maurer, Martin Haspelmath \& Magnus Huber. Leipzig: Max Planck Institute for Evolutionary Anthropology. (Available online at http://apics-online.info/contributions/9, Accessed on 2020-01-07.)

Essegbey, J., Migge, B. \& Winford, D. 2013. Cross-linguistic Influence in Language Creation (Special Issue). Lingua, 129(7): 1-8. 
Farquharson, J. 2013. Jamaican, in The Survey of Pidgin \& Creole Languages: English-based and Dutch-based Languages, Vol 1, edited by Susanne M. Michaelis, Philippe Maurer, Martin Haspelmath, \& Magnus Huber. Oxford: Oxford University Press: 81-91.

Farquharson, J. 2017. Linguistic Ideologies and the historical development of language use patterns in Jamaican music. Language \& Communication, 52(1): 7-18.

Fattier, D. 2013a. Haitian Creole, in The Survey of Pidgin \& Creole Languages: Portuguesebased, Spanish-based and French-based Languages, Vol 2, edited by Susanne M. Michaelis, Philippe Maurer, Martin Haspelmath, \& Magnus Huber. Oxford: Oxford University Press: 195-204.

Fattier, D. 2013b. Haitian Creole structure dataset, in Atlas of Pidgin and Creole Language Structures Online, edited by Susanne M. Michaelis, Philippe Maurer, Martin Haspelmath \& Magnus Huber. Leipzig: Max Planck Institute for Evolutionary Anthropology. (Available online at http://apics-online.info/contributions/49, Accessed on 2020-01-07.)

Foster, L. V. 2007. A brief history of Central America ( $2^{\text {nd }}$ Edition). New York: Facts on File Inc.

Garrett, P. 2000. 'High' Kweyol: The Emergence of a Formal Creole Register in St. Lucia, in Language Change and Language Contact in Pidgins and Creoles, edited by John McWhorter. Amsterdam: John Benjamins: 63-102.

Garrett, P. 2003. An "English Creole" that isn't: on the sociohistorical origins and linguistic classification of the vernacular English of St. Lucia, in Contact Englishes of the Eastern Caribbean Varieties of English around the World, edited by Michael Aceto \& Jeffrey Williams. Amsterdam: John Benjamins: 155-210.

Grant, A. P. 1999. A note on ethnolectal variation in Mathews' texts', in St. Kitts and the Atlantic Creoles: The Texts of Samuel Augustus Mathews in Perspective, edited by Philip Baker \& Adrienne Bruyn. London: Westminster University Press: 123-128. 
Hackert, S. 2013. Bahamian Creole, in The Survey of Pidgin \& Creole Languages: Englishbased and Dutch-based Languages, Vol 1, edited by Susanne M. Michaelis, Philippe Maurer, Martin Haspelmath, \& Magnus Huber. Oxford: Oxford University Press: 127138.

Hancock, I. 1986. The domestic hypothesis, diffusion and componentiality: An account of Atlantic Anglophone creole origins, in Substrata versus Universals in Creole Genesis, edited by Pieter Muysken \& Norval Smith. Amsterdam: John Benjamins: 71-102.

Hazaël-Massieux, G. 1996. Les créoles: Problèmes de genèse et de description. Aix-enProvince: Publications de l’Université de Provence.

Herzfeld, A. 1978. Tense and Aspect in Limon Creole. Kansas: The University of Kansas. Herzfeld, A. \& Moskowitz, D. 2004. The Limonese calypso as an identity marker, in Creoles, Contact and Language Change: Linguistic and social implications, edited by Genevieve Escure \& Armin Schwegler. Amsterdam: John Benjamins: 259-284.

Higman, B. W. 2011. A concise history of the Caribbean. Cambridge: Cambridge University Press.

Hinrichs, L. 2006. Codeswitching on the Web: English and Jamaican Creole in E-mail Communication. Amsterdam: John Benjamins.

Hinrichs, L. 2014. Diasporic mixing of World Englishes: The case of Jamaican Creole in Toronto, in The Variability of Current World Englishes, edited by Eugene Green \& Charles Meyer. Berlin: Mouton de Gruyter: 169-198.

Holm, J. 1988. Pidgins and Creoles: Volume 1, Theory and Structure. Cambridge: Cambridge University Press.

Holm, J. \& Patrick, P. 2001a. Comparative Creole Syntax. London: Battlebridge. (Westminster Creolistics Series Vol. 7). 
Holm, J. \& Patrick, P. 2001b. Introduction, in Comparative Creole Syntax, edited by John Holm \& Peter L. Patrick. London: Battlebridge: v-xii. (Westminster Creolistics Series Vol. 7).

Huttar, G. L., Essegbey, J. \& Ameka, F. K. 2007. Gbe and other West African sources of Suriname creole semantic structures: Implications for creole genesis. Journal of Pidgin and Creole Languages, 22(1): 57-72.

Huttar, G. L. \& Velantie, F. 1997. Ndyuka-Trio Pidgin, in Contact languages. A wider Perspective, edited by Sarah G. Thomason. Amsterdam: John Benjamins: 99-124.

Hymes, D. 1971. Pidginization and creolization of languages. Proceedings of a conference held at the University of the West Indies, Mona, Jamaica, April 1968. Cambridge: Cambridge University Press.

Jennings, W. \& Pfänder, S. 2018. Inheritance \& Innovation in Language Creation. A usagebased account of French Guianese Creole. London/New York: Palgrave Macmillan.

Keesing, R. M. 1988. Melanesian Pidgin and the Oceanic Substrate. Stanford: Stanford University Press.

Kleine de, Christa M. 2007. A morphosyntactic analysis of Surinamese Dutch as spoken by the creole population of Paramaribo Suriname. München: Lincom.

Kouwenberg, S. 2003. Twice as Meaningful: Reduplication in Pidgins, Creoles and Other Contact Languages. London: Battlebridge.

Kouwenberg, S. 2013a. Berbice Dutch, in The Survey of Pidgin \& Creole Languages: English-based and Dutch-based Languages, Vol 1, edited by Susanne M. Michaelis, Philippe Maurer, Martin Haspelmath, \& Magnus Huber. Oxford: Oxford University Press: 275-284.

Kouwenberg, S. 2013b. Papiamentu structure dataset, in Atlas of Pidgin and Creole Language Structures Online, edited by Susanne M. Michaelis, Philippe Maurer, Martin 
Haspelmath \& Magnus Huber. Leipzig: Max Planck Institute for Evolutionary

Anthropology. (Available online at http://apics-online.info/contributions/47, Accessed on 2020-01-06.)

Kouwenberg, S. \& Singler, J. V. 2008. Introduction, in The Handbook of Pidgin and Creole Studies, edited by Silvia Kouwenberg \& John V. Singler. Malden: Wiley-Blackwell: 1-16. Lacoste, V. 2017. The Caribbean, in The Oxford Handbook of World Englishes, edited by Makku Filppula, Juhani Klemola \& Devyani Sharma. Oxford: Oxford University Press: $389-408$.

Laëthier, M. 2011. Être migrant et Hä̈tien en Guyane. Paris: Éditions du CTHS.

Lalla, B. \& D'Costa, J. 1990. Language in Exile: Three Hundred Years of Jamaican Creole. Tuscaloosa: University of Alabama Press.

Lefebvre, C. 1998. Creole genesis and the acquisition of grammar: The case of Haitian creole. Cambridge: Cambridge University Press.

Lefebvre, C. 2011. Creoles, their substrates, and language typology. Amsterdam: John Benjamins.

Lefebvre, C. 2015. Relabeling in Language Genesis. New York: Oxford University Press. Léglise, I. 2003. The interplay of inherent tendencies and language contact on French object clitics, in The interplay of Variation and Change in Contact Settings, edited by Isabelle Léglise \& Claudine Chamoreau. Amsterdam: John Benjamins: 137-163.

Le Page, R. B. \& Tabouret-Keller, A. 1985. Acts of Identity: Creole-based Approaches to Language and Ethnicity. Cambridge: Cambridge University Press.

Lévi-Strauss, C. 1955. Tristes Tropiques. Paris: Librairie Plon.

Lipski, J. M. 1986. The Negros Congos of Panama: Afro-Hispanic creole language and cultures. Journal of Black Studies, 16(4): 409-428. 
Lipski, J. M. 2005. A history of Afro-Hispanic language. Five centuries, five continents. Cambridge: CUP.

Lipski, J. M. 2008. Afro-Bolivian Spanish. Madrid \& Frankfurt: Iberoamericana - Vervuert Ly, C. 2007. De l'influence du français et du créole guyanais sur le hmong parlé en Guyane, in Pratiques et attitudes linguistiques en Guyane: regards croisés, edited by Isabelle Léglise \& Bettina Migge. Paris: Editions: 159-170.

Managan, K. 2011. 'Koud Zy’: A glimpse into linguistic enregisterment on Kréyèl television in Guadeloupe. Journal of Sociolinguistics, 15(3): 299-322.

Maurer, P. 2013. Papiamentu, in The Survey of Pidgin \& Creole Languages: Portuguesebased, Spanish-based and French-based Languages, Vol 2, edited by Susanne M. Michaelis, Philippe Maurer, Martin Haspelmath, \& Magnus Huber. Oxford: Oxford University Press: 163-181.

McWhorter, J. H. 1999. The Afrogenesis hypothesis of plantation creole origin, in St Kitts and the Atlantic Creoles: The Texts of Samuel Agustus Mathews in Persprctive, edited by Phillip Baker \& Adrienne Bryun. London: University of Westminster Press: 111-52.

McWhorter, J. H. 2000. The Missing Spanish Creoles: Recovering the Birth of Plantation Contact Languages. Los Angeles: University of California Press.

McWhorter, J. H. 2002. The rest of the story: Restoring pidginization to creole genesis Theory. Journal of Pidgin and Creole Languages, 17(1): 1-48.

McWhorter, J. H. 2018. The Creole debate. Cambridge: Cambridge University Press.

McWhorter, J. H. \& Good, J. 2012. A grammar of Saramaccan creole. Berlin: Mouton de Gruyter.

Meira, S. \& Muysken, P. 2017. Cariban in contact: New perspectives on Trip-Ndyuka pidgin, in Boundaries and Bridges: Language Contact in Multilingual Ecologies, edited by Kofi Yakpo \& Pieter Muysken. Berlin: Mouton de Gruyter: 197-228. 
Meyerhoff, M. \& Walker, J. A. 2007. The persistence of variation in individual grammars: Copula absence in "urban sojourners" and their stay-at-home peers, Bequia (St Vincent and the Grenadines). Journal of Sociolinguistics, 11(3): 446-466.

Michaelis, S. 2008. Roots of Creole Structures: Weighing the Contribution of Substrates and Superstrates. Amsterdam: John Benjamins. (Creole Language Library 33)

Michaelis, S. \& APiCs Consortium. 2013a. Predicative adjectives, in The Atlas of Pidgin \& Creole language structures, edited by Susanne Michaelis, Philippe Maurer, Martin Haspelmath \& Magus Huber. Oxford: Oxford University Press: 294-297.

Michaelis, S. \& APiCs Consortium. 2013b. Predicative noun phrases and predicative locative phrases, in The Atlas of Pidgin \& Creole language structures, edited by Susanne Michaelis, Philippe Maurer, Martin Haspelmath \& Magus Huber. Oxford: Oxford University Press: 302-305.

Michaelis, S., Maurer, P., Haspelmath, M. \& M. Huber (eds.). 2013a. The Survey of Pidgin \& Creole Languages, Vols. 1-3. Oxford: OUP. https://apics-online.info/

Michaelis, S., Maurer, P., Haspelmath, M. \& M. Huber (eds.). 2013b. The Atlas of Pidgin \& Creole Languages Structures. Oxford: OUP. https://apics-online.info/

Migge, B. 1996. Copula variability in the Belize continuum and the notion of the creole continuum, in Sociolinguistic Variation: Data, Theory, and Analysis. Selected papers from NWAV 23 at Stanford, edited by Jennifer Arnold, Renée Blake, Brad Davidson, Scott Schwenter \& Julie Solomon. Stanford: CSLI: 129-150.

Migge, B. 2002. The origin of the copulas (d/n)a and de in the Eastern Maroon Creole. Diachronica, 19(1): 81-133.

Migge, B. 2003. Creole formation as language contact: The case of the Suriname Creoles. Amsterdam: John Benjamins. (Creole Language Library 25) 
Migge, B. 2011. Negotiating Social Identities on an Eastern Maroon Radio Show. Journal of Pragmatics, 43(6): 1495-1511.

Migge, B. 2013a. Nengee, in The Survey of Pidgin \& Creole Languages: English-based and Dutch-based Languages, Vol 1, edited by Susanne M. Michaelis, Philippe Maurer, Martin Haspelmath, \& Magnus Huber. Oxford: Oxford University Press: 39-48.

Migge, B. 2013b. Nengee structure dataset, in Atlas of Pidgin and Creole Language Structures Online, edited by Susanne M. Michaelis, Philippe Maurer, Martin Haspelmath \& Magnus Huber. Leipzig: Max Planck Institute for Evolutionary Anthropology. (Available online at http://apics-online.info/contributions/4, Accessed on 2020-01-07.)

Migge, B. 2015. The role of discursive information in analyzing multilingual practices, in Code-switching at the crossroads between structural and sociolinguistic perspectives, edited by Gerald Stell \& Kofi Yakpo. Berlin: Mouton de Gruyter: 185-206.

Migge, B. \& Goury, L. 2008. Between contact and internal development: Towards a multilayered explanation for the development of the TMA system in the creoles of Suriname', in Roots of Creole Structures: Weighing the Contribution of Substrates and Superstrates, edited by Susanne Michaelis. Amsterdam: John Benjamins: 300-331. (Creole Language Library 33)

Migge, B. \& Léglise, I. 2013. Exploring Language in a Multilingual Context: Variation, Interaction and Ideology in Language Documentation. Cambridge: Cambridge University Press.

Migge, B. \& Léglise, I. 2015. Assessing the sociolinguistic situation of the Maroon Creoles. Journal of Pidgin and Creole Languages, 30 (1): 63-115.

Migge, B., Léglise, I. \& Bartens, A. 2010. Creole in Education: An Appraisal of Current Programs and Projects. Amsterdam: John Benjamins. 
Migge, B. \& Smith, N. 2007. Substrate influence in creole genesis (Special Issue). Journal of Pidgin and Creole Languages, 22 (1): 1-15.

Migge, B. \& van den Berg, M. 2009. Creole learner varieties in the past and in the present: implications for creole development. Language, Interaction and Acquisition, 1 (1): 253282.

Mohan, P. 1990. The rise and fall of Trinidad Bhojpuri. International Journal of the Sociology of Language, 85: 21-30.

Moll, A. 2015. Jamaican Creole Goes Web: Sociolinguistic Styling and Authenticity in a Digital 'Yaad'. Amsterdam: John Benjamins.

Moore, D., Facundes, S. \& Pires, N. 1994. Nheengatu (Língua Geral Amazonica), its history, and the effects of language contact, in Report 8: Survey of California and other Indian Languages: Proceedings of the Meeting of the Society for the Study of the Indigenous language of the Americas, July 2-4, 1993, edited by M. Langdon. Survey of California and Other Indian Languages: 93-118.

Mufwene, S.. 2008. Language evolution: contact, competition and change. London: Continuum.

Mühleisen, S. 2002. Creole Discourse: Exploring Prestige Formation and Change across Caribbean English-lexicon Creoles. Amsterdam: John Benjamins. (Creole Language Library 24)

Mühleisen, S. \& Migge, B. 2005. Politeness and Face in Caribbean Creoles. Amsterdam: John Benjamins.

Muysken, P. 1980. Sources for the study of Amerindian contact vernaculars in Ecuador. Amsterdam Creole Studies, 3: 66-82.

Muysken, P. 2013. Media Lengua, in The Survey of Pidgin \& Creole Languages: Contact Languages Based on Languages from Africa, Asia, Australia, and the Americas, Vol 3, 
edited by Susanne M. Michaelis, Philippe Maurer, Martin Haspelmath, \& Magnus Huber. Oxford: Oxford University Press: 143-148.

Muysken, P. 2017. The transformation of a colonial language: Surinamese Dutch, in Boundaries and Bridges: Language Contact in Multilingual Ecologies, edited by Kofi Yakpo \& Pieter Muysken. Berlin: Mouton de Gruyter: 283-310.

Muysken, P. \& Smith, N. 2015. Surviving the Middle Passage: The West Africa-Surinam Sprachbund. Berlin: Walter de Gruyter.

Myers-Scotton, C. 1993. Dueling languages. Oxford: Clarendon Press.

Operé, F. 2008. Indian Captivity in Spanish America: Frontier Narratives. Charlottesville: University of Virginia Press.

Parkvall, M. 2008. The simplicity of creoles in a cross-linguistic perspective, in Language Complexity: Typology, Contact, Change, edited by Matti Miestamo, Kaius Sinnemki \& Fred Karlsson. Amsterdam: John Benjamins: 265-285.

Patrick, P. L. 1999. Urban Jamaican Creole: Variation in the Mesolect. Amsterdam and Philadelphia: John Benjamins Publishers.

Perez, D. 2015. Traces of Portuguese in Afro-Yungueño Spanish? Journal of Pidgin and Creole Languages, 30(2): 307-343.

Pfänder, S. 2013. Guyanais, in The Survey of Pidgin \& Creole Languages: Portuguese-based, Spanish-based and French-based Languages, edited by Susanne M. Michaelis, Philippe Maurer, Martin Haspelmath, \& Magnus Huber, Vol 2. Oxford: Oxford University Press: 220-228. https://apics-online.info/

Pollard, V. 1999. Beyond grammar: Teaching English in an Anglophone Creole Environment, in Creole Genesis, Attitudes and Discourse, edited by John. R. Rickford \& Susanne Romaine. Amsterdam: John Benjamins: 323-333. 
Prescod, P. 2013. Vincentian Creole structure dataset, in Atlas of Pidgin and Creole Language Structures Online, edited by Susanne M. Michaelis, Philippe Maurer, Martin Haspelmath

\& Magnus Huber. Leipzig: Max Planck Institute for Evolutionary Anthropology. (Available online at http://apics-online.info/contributions/7, Accessed on 2020-01-07.) Prescod, P. 2015. Language Issues in Saint Vincent and the Grenadines. Amsterdam: John Benjamins.

Price, R. 1996. Introduction: Maroons and Their Communities, in Maroon Societies: Rebel Slave Communities in the Americas ( $3^{\text {rd }}$ edition), edited Richard Price. Baltimore: Johns Hopkins University Press: 1-30.

Price, R. \& Price, S. 2003. Les Marrons. Chateauneuf-le-Rouge France: Vents d'ailleurs. Rickford, J. R. 1974. The insights of the mesolect, in Pidgins and Creoles: Current Trends and Perspectives, edited by David DeCamp and Ian Hancock. Washington, DC: Georgetown University Press: 92-117.

Rickford, J. R. 1985. Standard and non-Standard language attitudes in a creole continuum, in Language of Inequality, edited by Nassa Wolfson \& Joan Manes. Berlin: Mouton Publishers: $145-160$.

Rickford, J. R. 1986. The need for new approaches to social class analysis in sociolinguistics. Language and Communication, 6(3): 215-212.

Rickford, J. R. 1988. Connections between sociolinguistics and pidgin-creole studies. International Journal of the Sociology of Language, 71: 51-57.

Rickford, J. R. 1991. Sociolinguistic variation in Cane Walk: A quantitative case study, in English Around The World: Sociolinguistic Perspectives, edited by Jenny Cheshire. Cambridge: Cambridge University Press: 609-616. 
Rickford, J. R. 2011. Le Page's theoretical and applied legacy in sociolinguistics and creole studies, in Variation in the Caribbean: From Creole Continua to Individual Agency, edited by Lars Hinrichs \& Joseph T. Farquharson. Amsterdam: John Benjamins: 251-272.

Rickford, J. R. 2019a. Variation, Versatility and Change in Sociolinguistics and Creole Studies. Cambridge: Cambridge University Press.

Rickford, J. R. 2019b. Chapter 9 - The social and the Linguistic in Sociolinguistic Variation, in Variation, Versatility and Change in Sociolinguistics and Creole Studies, edited by John R. Rickford. Cambridge: Cambridge University Press: 197-206.

Rickford, J. R. \& Handler, J. 1994. Textual evidence on the nature of early Barbadian speech, 1676-1835. Journal of Pidgin and Creole Languages, 9(2): 221-225.

Riley, C. C. 1952. Trade Spanish of the Piñaguero Panare. Studies in Linguistics, 10(3): 6-11. Roberts, S. 2014. Patagonian Jargon Spanish: A new look into a little-known contact variety. Paper presented at the joint SCL and SPCL meeting in Aruba.

Rojas-Berscia, L. \& Shi, Jia Ann. 2017. Hakka as spoken in Suriname, in Boundaries and Bridges: Language Contact in Multilingual Ecologies, Kofi Yakpo \& Pieter Muysken. Berlin: Mouton de Gruyter: 179- 196.

Sabino, R. 2012. Language contact in the Danish West Indies: Giving Jack his jacket. Leiden: Brill.

Sankar, M. \& Winer, L. 2006. Multilingual code-switching in Quebec Rap: Poetry, Pragmatics and Performativity. International Journal of Multilingualism, 3(3): 173-192.

Schwegler, A. 2000. The African Vocabulary of Palenque (Colombia). Journal of Pidgin and Creole Languages, 15 (2): 241-312.

Schwegler, A. 2013. Palenquero, in The Survey of Pidgin \& Creole Languages: Portuguesebased, Spanish-based and French-based Languages, Vol 2, edited by Susanne M. 
Michaelis, Philippe Maurer, Martin Haspelmath, \& Magnus Huber. Oxford: Oxford University Press: 182-192.

Sessarego, S. 2009. Gender agreement variation in the Afro-Bolivian Determiner Phrase: The Interplay of Social and Linguistic Factors. Revista Iberoamericana de Lingüística, 4(2): 135-146.

Sessarego, S. 2015. Afro-Peruvian Spanish: Spanish slavery and the legacy of Spanish Creoles. Amsterdam: John Benjamins.

Shields-Brodber, K. 1992. Dynamism and assertiveness in Public Voice: Turn- Taking and Code-Switching in Radio Shows in Jamaica. Pragmatics, 2(4): 487-504.

Siegel, J. 2006. Literacy in Pidgin and Creole Languages. Current Issues in Language Planning, 6(2): 143-163.

Siegel, J. 2008. The Emergence of Pidgin and Creole Languages. Oxford: Oxford University Press.

Sidnell, J. 1999. Gender and pronominal variation in an Indo-Guyanese Creole speaking community. Language in Society, 28(3): 367-99.

Sidnell, J. 2003. Constructing and managing male exclusivity in talk-in-interaction, in Handbook of Language and Gender, edited by Janet Holmes \& Miriam Meyerhoff. Oxford: Blackwell, 327-352.

Simson, A. 1879. Notes on the Piojes of the Putumayo. Journal of the Anthropological Institute of Great Britain and Ireland, 8(2): 210-222.

Singler, J. V. 1988. The homogeneity of the substrate as a factor in pidgin/creole genesis. Language, 64: 27-51.

Singler, J. V. 1995. The demographics of creole genesis in the Caribbean: A comparison of Martinique and Haiti, in The early stages of creolization, edited by Jacques Arends. Amsterdam: John Benjamins: 203-232. 
Smith, N. S. H. 1987. The Genesis of the Creole Languages of Surinam. PhD dissertation, Universiteit van Amsterdam.

Smith, N. 2008. Creole Phonology, in The Handbook of Pidgin and Creole Studies, edited by Silvia Kouwenberg \& John V. Singler. Malden: Wiley-Blackwell: 98-129.

Smith, N. 2015. Ingredient X: The shared African lexical element in the English-lexifier Atlantic Creoles, and the theory of rapid creolization, in Surviving the Middle Passage: The West Africa-Surinam Sprachbund, edited by Pieter Muysken \& Norval Smith. Berlin: Walter de Gruyter: 67-106.

Tobler, S. J. 1983. The Grammar of Karipuna Creole. Brasilia: Summer Institute of Linguistics.

van den Berg, M. 2007. A Grammar of Early Sranan. Zetten: Drukkerij Manta.

Van Rossem, C. \& van der Voort, H. 1996. Die Creol Taal: 250 Years of Negerhollands Texts. Amsterdam: Amsterdam University Press.

Versteegh, K. 2008. Non-indo-European Pidgins and Creoles, in The Handbook of Pidgin and Creole Studies, edited by Silvia Kouwenberg \& John V. Singler. Malden: WileyBlackwell: 158-186.

Villerius, S. 2017. Developments in Surinamese Javanese, in Boundaries and Bridges: Language Contact in Multilingual Ecologies, edited by Kofi Yakpo \& Pieter Muysken. Berlin: Mouton de Gruyter: 152-178.

Walker, J. A. \& Meyerhoff, M. 2015. Bequia, in Further studies in the Lesser-known varieties of English, edited by Jeffery P. Williams, Edgar W. Schneider, Peter Trudgill \& Daniel Schreier. Cambridge: Cambridge University Press: 128-143.

Williams, J. P. \& Myrick, C. 2015. Saban English, in Further studies in the Lesser-known varieties of English, Jeffery P. Williams, Edgar W. Schneider, Peter Trudgill \& Daniel Schreier. Cambridge: Cambridge University Press: 144-164. 
Winer, L. 1984. Early Trinidadian English Creole: The Spectator Texts. English World-Wide, 5(2): 181-210.

Winford, D. 1985. The Concept of "Diglossia" in Caribbean Creole Situations. Language in Society, 14 (3): 345-356.

Winford, D. 1991. The Caribbean, in English around the world: sociolinguistic perspectives, edited by Jenny Cheshire. Cambridge: Cambridge University Press: 565-584.

Winford, D. 1993. Predication in Caribbean English Creoles. Amsterdam: John Benjamins.

Winford, D. 1997. Re-examining Caribbean English Creole continua. World Englishes, 16(2): 233-79.

Winford, D. 2003. An Introduction to Contact Linguistics. Oxford: Blackwell.

Winford, D. 2018. Creole Tense-Mood-Aspect systems. Annual Review of Linguistics 4, 1993-212.

Winford, D. \& Plag, I. 2013. Sranan, in The Survey of Pidgin \& Creole Languages: Englishbased and Dutch-based Languages, Vol 1. edited by Susanne M. Michaelis, Philippe Maurer, Martin Haspelmath, \& Magnus Huber. Oxford: Oxford University Press: 15-26.

Yakpo, K. 2017a. Creole in transition: Contact with Dutch and typological change in Sranan, in Boundaries and Bridges: Language Contact in Multilingual Ecologies, edited by Kofi Yakpo \& Pieter Muysken. Berlin: Mouton de Gruyter: 57-86.

Yakpo, K. 2017b. Out of India: Language contact and change in Sarnami (Caribbean Hindustani), in Boundaries and Bridges: Language Contact in Multilingual Ecologies, edited by Kofi Yakpo \& Pieter Muysken. Berlin: Mouton de Gruyter: 129-149.

Young, C. 1973. Belize Creole: A study of the creolized English Spoken in the City of Belize, in its cultural and social setting. PhD Dissertation, University of York. 
Youssef, V.1996. Varilingualism: The Competence behind Code-Mixing in Trinidad and Tobago. Journal of Pidgin and Creole Languages, 11(1): 1-22. 